\title{
Organization of research team for nano-associated safety assessment in effort to study nanotoxicology of zinc oxide and silica nanoparticles
}

This article was published in the following Dove Press journal:

International Journal of Nanomedicine

15 December 2014

Number of times this article has been viewed

\author{
Yu-Ri Kim ${ }^{1, *}$ \\ Sung Ha Park $2, *$ \\ Jong-Kwon $\mathrm{Lee}^{3}$ \\ Jayoung Jeong ${ }^{3}$ \\ Ja Hei Kim ${ }^{4}$ \\ Eun-Ho Meang ${ }^{5}$ \\ Tae Hyun Yoon ${ }^{6}$ \\ Seok Tae $\operatorname{Lim}^{7}$ \\ Jae-Min $\mathrm{Oh}^{8}$ \\ Seong Soo A An ${ }^{9}$ \\ Meyoung-Kon Kim' \\ 'Department of Biochemistry and Molecular \\ Biology, Korea University Medical School and \\ College, Seoul, South Korea; ${ }^{2}$ Department of \\ Biochemistry, University of Bath, Bath, UK; \\ ${ }^{3}$ Toxicological Research Division, National \\ Institute of Food and Drug Safety Evaluation, \\ Chungchungbuk-do, ${ }^{4}$ Consumers Korea, \\ Chongro-ku, ${ }^{5}$ General toxicology team, Korea \\ Testing and Research Institute, 'Laboratory of \\ Nanoscale Characterization and Environmental \\ Chemistry, Department of Chemistry, College \\ of Natural Sciences, Hanyang University, Seoul, \\ ${ }^{7}$ Department of Nuclear Medicine, Chonbuk \\ National University Medical School, Jeonju, \\ Jellabuk-Do, ${ }^{8}$ Department of Chemistry and \\ Medical Chemistry, College of Science and \\ Technology, Yonsei University, Gangwon-do, \\ 'Department of Bionanotechnology, Gachon \\ Medical Research Institute, Gachon University, \\ Seongnam, South Korea \\ *Authors contributed equally to this work
}

Correspondence: Seong Soo A An

Department of Bionanotechnology, Gachon Medical Research Institute,

Gachon University, Sungnam-si,

Gyeonggi-do 46I-70I, South Korea

Tel +82 3I 7508755

Fax +82 3। 7508755

Email seongaan@gachon.ac.kr

Meyoung-Kon Kim

Department of Biochemistry and

Molecular Biology, Korea University

Medical School and College,

Anam-Dong $5 \mathrm{Ga}$, Seoungbuk-Gu,

Seoul I35-70I, South Korea

$\mathrm{Tel}+82222866184$

Fax +8229230480

Email jerrykim@korea.ac.kr
Abstract: Currently, products made with nanomaterials are used widely, especially in biology, biotechnologies, and medical areas. However, limited investigations on potential toxicities of nanomaterials are available. Hence, diverse and systemic toxicological data with new methods for nanomaterials are needed. In order to investigate the nanotoxicology of nanoparticles (NPs), the Research Team for Nano-Associated Safety Assessment (RT-NASA) was organized in three parts and launched. Each part focused on different contents of research directions: investigators in part I were responsible for the efficient management and international cooperation on nano-safety studies; investigators in part II performed the toxicity evaluations on target organs such as assessment of genotoxicity, immunotoxicity, or skin penetration; and investigators in part III evaluated the toxicokinetics of NPs with newly developed techniques for toxicokinetic analyses and methods for estimating nanotoxicity. The RT-NASA study was carried out in six steps: need assessment, physicochemical property, toxicity evaluation, toxicokinetics, peer review, and risk communication. During the need assessment step, consumer responses were analyzed based on sex, age, education level, and household income. Different sizes of zinc oxide and silica NPs were purchased and coated with citrate, L-serine, and L-arginine in order to modify surface charges (eight different NPs), and each of the NPs were characterized by various techniques, for example, zeta potentials, scanning electron microscopy, and transmission electron microscopy. Evaluation of the "no observed adverse effect level" and systemic toxicities of all NPs were performed by thorough evaluation steps and the toxicokinetics step, which included in vivo studies with zinc oxide and silica NPs. A peer review committee was organized to evaluate and verify the reliability of toxicity tests, and the risk communication step was also needed to convey the current findings to academia, industry, and consumers. Several limitations were encountered in the RT-NASA project, and they are discussed for consideration for improvements in future studies. Keywords: nanomaterials, nanotoxicity, toxicokinetics, physicochemical property, peer review

\section{Introduction}

Nanoparticles (NPs) refer to compounds or particles with size ranging between 1 and 100 nanometers. Products made from NPs are already commercially used in the fields of biology, biotechnology, and medicine, including use in drug delivery, tissue engineering, tumor destruction, and as biosensors. ${ }^{1-3}$ Despite their wide use, limited results and studies focused on their potential toxicity, and the lack of toxicological data and proper characterization by several orthogonal techniques on NPs did not allow for enough risk evaluation and assessment. Furthermore, with increases in industrial scale production of NPs, the unique and diverse physicochemical properties of NPs suggest that their toxicological properties may differ in small scale production from those of corresponding bulk materials. ${ }^{4-6}$ Therefore, it was necessary to obtain the toxicity data of NPs with 
diverse physicochemical properties, especially using newly available toxicity test methods.

\section{Structure of Research Team for Nano-Associated Safety Assessment (RT-NASA)}

The RT-NASA was recruited and organized into three parts, I, II, and III, which coincided perfectly with the interests of the Ministry of Food and Drug Safety (Figure 1). Investigators in part I were responsible for the efficient management and international cooperation in nano-safety studies. Investigators in part II performed the toxicity evaluations of NPs on target organs, and investigators in part III evaluated the toxicokinetics of NPs. In parts I-III, we investigated the best management framework in organizing various research teams and arranging researchers with clear roles, experiments, and expectations and especially in harmonizing and unifying each team to construct a clear outcome. We also discussed intensely the most efficient methods for designing accurate appraisal systems for this multidisciplinary project. The study duration was from 2010 to 2013.

\section{Part I: research for efficient management and international cooperation in nanosafety study}

Part I examined the efficient management and the promotion of international cooperation in nano-safety study.
Risk communication of nanomaterials between consumers and experts was investigated, mainly by focusing on risk perceptions by each sector. Scientifically verified information on the hazards of nanomaterials were shared. Part I also analyzed the most current studies and considered the future direction of nanotoxicity research and the international cooperation for these studies.

\section{Part II: toxicity evaluation on the target organs of nanomaterials}

Researchers in part II principally performed research to evaluate the toxicity of NPs on target organs, including assessment of genotoxicity, immunotoxicity, dermal toxicity, reproductive and developmental toxicities through various exposure routes (oral administration, intravenous injection, and skin penetration).

\section{Part III: toxicokinetic study of nanomaterials}

Toxicokinetic studies of NPs were carried out in part III, which mainly focused on the absorption, distribution, metabolism, and excretion study of NPs from various exposure routes and physicochemical properties. New techniques and estimation methods for toxicokinetic analyses were developed in this study, with quantitative analysis for nanotoxicity.

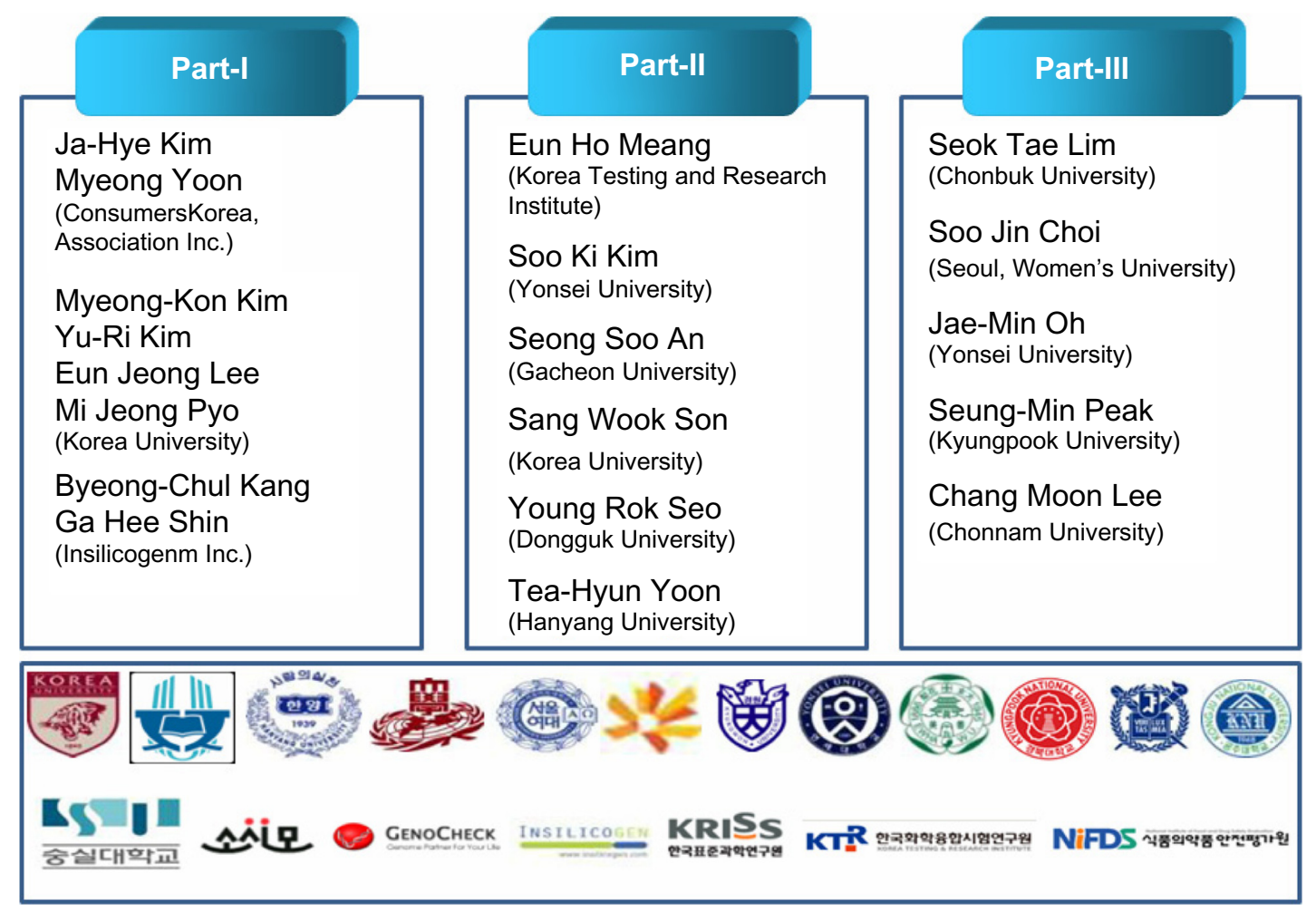

Figure I Structure of Research Team for Nano-Associated Safety Assessment. 


\section{Function and outcome of RT-NASA}

Figure 2 presents the six steps for nanosafety and assessment studies of two different types of NPs, silica $\left(\mathrm{SiO}_{2}\right)$ and zinc oxide $(\mathrm{ZnO})$, in RT-NASA: need assessment, physicochemical property, toxicity evaluation, toxicokinetics, peer review, and risk communication. $\mathrm{SiO}_{2} \mathrm{NPs}$ are currently being used in chemical-mechanical polishing, varnishes, printer toners, cosmetics, foodstuffs, and biomedical devices. ${ }^{7,8}$ In addition, ZnO NPs have commonly been used primarily in sunscreen products because they absorb ultraviolet light,, 10 and they have been explored as photoconductive materials in electronics, including cellular phones and iPods. ${ }^{11,12}$ During the assessment step, the latest results from various investigations of nanotoxicity and international cooperation studies were analyzed. Studies on the absorption, biodistribution, metabolism, and persistence of NPs due to their physicochemical properties and the various routes of exposure were discussed and the decision to perform subsequent assessments was determined. Toxicity evaluations of NPs on target organs by assessment of genotoxicity, immunotoxicity, dermal toxicity, reproductive and developmental toxicity of NPs by oral administration, or skin penetration were then examined. Test methods for evaluating nanotoxicity were developed and evaluated. A possible patent on this developed analytical method for in vitro characterization of NPs could be one of the outstanding outcomes of the RT-NASA project. A study focusing on risk communication between consumers and industries regarding nanosafety investigations was also included in the six steps of the RT-NASA. The interpreted results established by the RT-NASA are summarized in Table 1 .

\section{Need assessment of consumers and experts about nanotechnology}

In order to assess the level of consumer awareness, we analyzed their responses in addressing knowledge of and encounters with NPs, based on sex, age, level of education, and average monthly household income. Analyses of the results indicated no significant difference in the responses by sex, age, and level of education. However, significant differences in the responses were observed from average monthly household income. Moreover, when we compared the awareness of nanotechnology between consumers and experts, we found that consumers had a more positive attitude toward nanotechnology and its application although they had lower awareness of it than the expert group. Therefore, we suggest that a communication system, including educational and promotional programming, should be established to address consumer expectations and concerns.

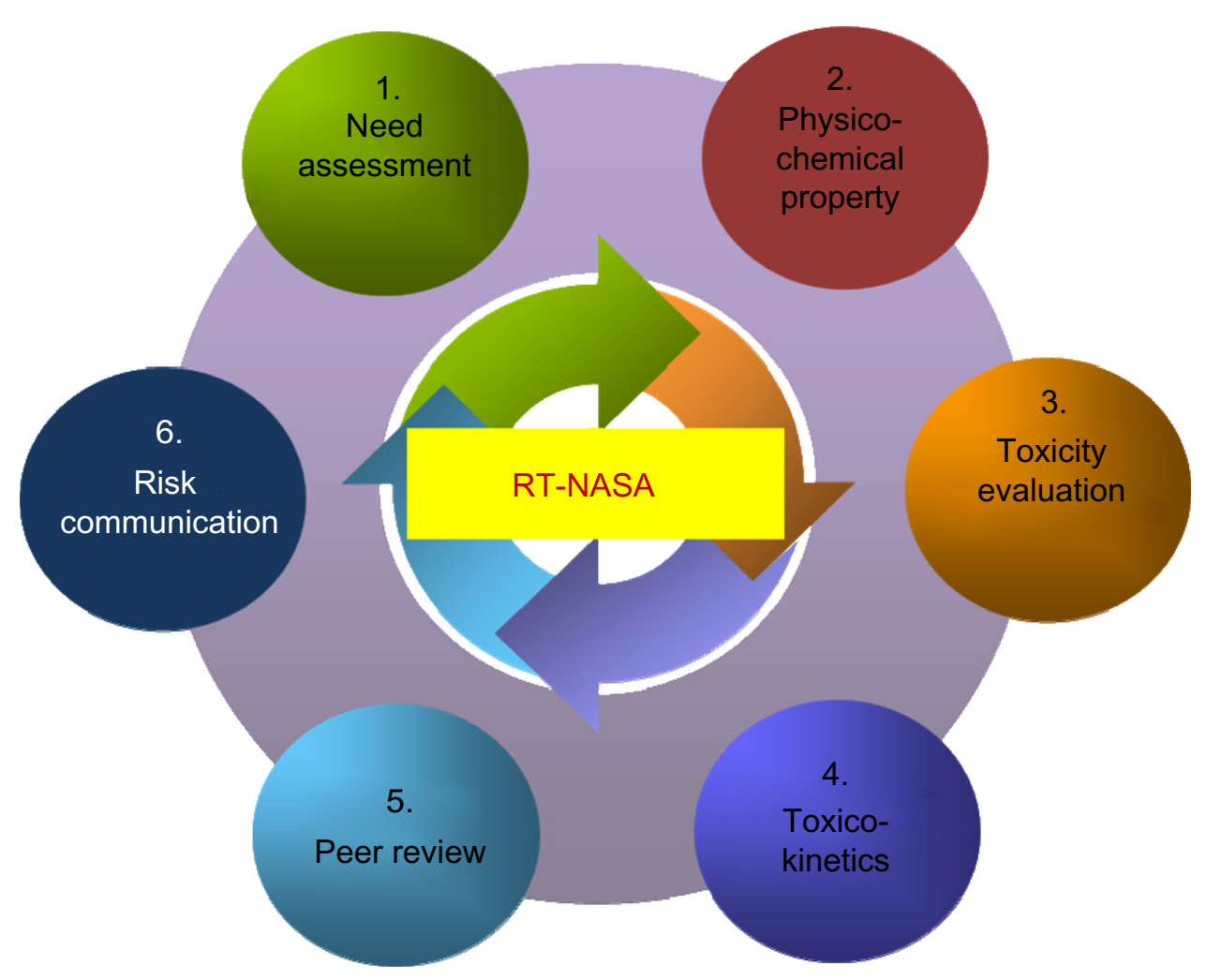

Figure 2 Six functional steps of the nanosafety process established by the Research Team for Nano-Associated Safety Assessment (RT-NASA). 
Table I Summarized results of Research Team for Nano-Associated Safety Assessment (RT-NASA)

\begin{tabular}{|c|c|}
\hline Number & Article title \\
\hline I & $\begin{array}{l}\text { Organization of RT-NASA in an effort to study } \\
\text { nanotoxicology of zinc oxide and silica nanoparticles }\end{array}$ \\
\hline 2 & $\begin{array}{l}\text { Interactive survey of consumer awareness of } \\
\text { nanotechnologies and nanoparticles in consumer products }\end{array}$ \\
\hline 3 & $\begin{array}{l}\text { Comparative analysis of nanotechnology awareness in } \\
\text { consumers and experts }\end{array}$ \\
\hline 4 & $\begin{array}{l}\text { Surface treatment of } \mathrm{SiO}_{2} \text { nanoparticles for stable and } \\
\text { charge-controlled colloidal } \mathrm{SiO}_{2}\end{array}$ \\
\hline 5 & $\begin{array}{l}\text { Physicochemical properties of surface charge modified } \\
\text { ZnO nanoparticles with different particle sizes }\end{array}$ \\
\hline 6 & $\begin{array}{l}\text { Effects of surface modifying ligands on the colloidal } \\
\text { stability of } \mathrm{ZnO} \text { nanoparticle dispersions in in vitro } \\
\text { cytotoxicity test media }\end{array}$ \\
\hline 7 & $\begin{array}{l}\text { Toxicity of } 90 \text {-day orally administered colloidal } \mathrm{SiO}_{2} \\
\text { nanoparticles in rats }\end{array}$ \\
\hline 8 & $\begin{array}{l}\text { 90-days subchronic oral toxicity of negative charged } \\
\mathrm{ZnO} \text { nanoparticles }(20 \mathrm{~nm}) \text { in SD rats }\end{array}$ \\
\hline
\end{tabular}

9 90-days subchronic oral toxicity of positive charged $\mathrm{ZnO}$ nanoparticles $(20 \mathrm{~nm})$ in SD rats

Toxicity of $100 \mathrm{~nm} \mathrm{ZnO}$ nanoparticles: a report of 90-day repeated oral administration in SD rats Evaluation of $\mathrm{SiO}_{2}$ nanoparticles toxicity after topical exposure for 90 days

Toxicity of $\mathrm{ZnO}$ nanoparticle: a report of a 90 -day repeated dose dermal toxicity study in rats Prenatal and developmental toxicity study of $\mathrm{ZnO}$ nanoparticles (20 nm, negatively charged) in rats Prenatal and developmental toxicity study of $\mathrm{ZnO}$ nanoparticles (20 nm, positively charged) in rats $\mathrm{SiO}_{2}$ nanoparticles defect the genotoxic potential in in vitro and in vivo system Immunotoxicity of $\mathrm{SiO}_{2}$ nanoparticles with different size and electrostatic charge

Immunotoxicity of $\mathrm{ZnO}$ nanoparticles with different size and electrostatic charge

Analysis of $\mathrm{SiO}_{2}$ nanoparticles binding proteins in rat blood and brain homogenate

Analysis of $\mathrm{ZnO}$ nanoparticles binding proteins in rat blood

Permeability and toxicity of $\mathrm{ZnO}$ and $\mathrm{SiO}_{2}$ nanoparticles to blood-brain barrier using Evans blue and TEM In vitro cytotoxicity of $\mathrm{SiO}_{2}$ or $\mathrm{ZnO}$ nanoparticles with different sizes and surface charges on U373 MG human glioblastoma cells

Optical imaging of absorption and distribution of RITC$\mathrm{SiO}_{2}$ nanoparticles after oral administration

Tissue distribution and excretion kinetics of oral $\mathrm{SiO}_{2}$ nanoparticles in rats

Biokinetics of $\mathrm{ZnO}$ nanoparticles: toxicokinetics, biological fates, and protein interaction

Current investigations on genotoxicity of metal oxide nanoparticles: carcinogenic/genotoxic potential, relevant mechanisms and biomarkers, artifacts and limitations

Abbreviations: RITC, rhodamine isothiocyanate; SD, Sprague Dawley; $\mathrm{SiO}_{2}$, silica; TEM, transmission electron microscopy; $\mathrm{ZnO}$, zinc oxide.

\section{Physicochemical properties of $\mathrm{ZnO}$ and $\mathrm{SiO}_{2} \mathrm{NPs}$}

$\mathrm{ZnO}$ and $\mathrm{SiO}_{2} \mathrm{NPs}$ of various sizes were purchased and coated with citrate, L-serine, or L-arginine (R) to modify their surface charge. ${ }^{13,14}$ Powder-phase $\mathrm{ZnO}$ NPs with different particle sizes ( $20 \mathrm{~nm}$ and $100 \mathrm{~nm}, \mathrm{ZnO}^{\mathrm{SM} 20}$ and $\mathrm{ZnO}^{\mathrm{AE} 100}$ ) were coated with citrate or $\mathrm{L}$-serine to induce a negative or positive surface charge, respectively, to yield the negativelysurface-charged $\mathrm{ZnO}$ NPs $\left(\mathrm{ZnO}^{\mathrm{SM} 20[-]}\right.$ and $\left.\mathrm{ZnO}^{\mathrm{AE1} 100[-]}\right)$ and the positively-surface-charged $\mathrm{ZnO}$ NPs $\left(\mathrm{ZnO}^{\mathrm{SM} 20[+]}\right.$ and $\left.\mathrm{ZnO}^{\mathrm{AE} 100[+]}\right)$. The colloidal $\mathrm{SiO}_{2} \mathrm{NPs}$ with $20 \mathrm{~nm}$ and $100 \mathrm{~nm}$ $\left(\mathrm{SiO}_{2}{ }^{\mathrm{EN} 20[-]}\right.$ and $\left.\mathrm{SiO}_{2}{ }^{\mathrm{EN} 100[-]}\right)$ diameter sizes were mixed with R solutions $\left(\mathrm{SiO}_{2}{ }^{\mathrm{EN} 20[\mathrm{R}]}\right.$ and $\left.\mathrm{SiO}_{2}{ }^{\mathrm{EN} 100[\mathrm{R}]}\right)$ to modify the surface charges of the colloidal $\mathrm{SiO}_{2}$ NPs.

The physicochemical properties of the prepared NPs $\mathrm{ZnO}^{\mathrm{SM} 20(-)}, \mathrm{ZnO}^{\mathrm{SM} 20(+)}, \mathrm{ZnO}^{\mathrm{AE} 100(-)}, \mathrm{ZnO}^{\mathrm{AE} 100(+)}, \mathrm{SiO}_{2}{ }^{\mathrm{EN} 20(-)}$, $\mathrm{SiO}_{2}{ }^{\mathrm{EN} 20(\mathrm{R})}, \mathrm{SiO}_{2}{ }^{\mathrm{EN} 100(-)}, \mathrm{SiO}_{2}{ }^{\mathrm{EN} 100(\mathrm{R})}$ - were characterized using scanning electron microscopy, transmission electron microscopy, X-ray diffraction, X-ray photoelectron spectroscopy, Fourier transform-infrared spectroscopy, Brunauer Emmett Teller (BET), zeta potential, dynamic light scattering, and inductively coupled plasma for the parameters of particle size, crystalline phase, chemical composition, chemical property, surface chemistry, surface charge, size distribution in aqueous suspension, and solubility. ${ }^{13,14}$ According to microscopic studies, it was verified that NPs had primary particle sizes of 10 30 nm for $\mathrm{ZnO}^{\mathrm{SM} 20(-)}$, $\mathrm{ZnO}^{\mathrm{SM} 20(+)}, \mathrm{SiO}_{2}{ }^{\mathrm{EN} 20(-)}$ and $\mathrm{SiO}_{2}{ }^{\mathrm{EN} 20(-)}$ and primary particle sizes of 70 100 nm for $\mathrm{ZnO}^{\mathrm{AE} 100(-)}, \mathrm{ZnO}^{\mathrm{AE} 100(+)}, \mathrm{SiO}_{2}{ }^{\mathrm{EN} 100(-)}$, and $\mathrm{SiO}_{2}{ }^{\mathrm{EN} 100(\mathrm{R})}$. X-ray diffraction showed that $\mathrm{ZnO}$ and $\mathrm{SiO}_{2}$ had Wurtzite and amorphous phase, respectively. From X-ray photoelectron spectroscopy and Fourier transforminfrared spectroscopy, the chemical composition, chemical property, and surface chemistry of NPs were well characterized. All the NPs were determined to have metal oxide phase with intended surface coating moieties. Through analysis of nitrogen adsorption-desorption isotherm using the BET method, we could evaluate the specific surface area of NPs. Generally, ZnO NPs showed relatively smaller specific surface area than $\mathrm{SiO}_{2}$ NPs, possibly due to the formation of agglomerates. The slight decreases in specific surface area after organic coating was also observed due to the increases in particle size. The surface charge of aspurchased $\mathrm{ZnO}$ and $\mathrm{SiO}_{2}$ NPs was determined to be positive and highly negative, respectively, in neutral $\mathrm{pH}$. The surface charge of $\mathrm{ZnO}$ coated with either L-serine or citrate resulted in positive and negative values, respectively, and 
R-coated $\mathrm{SiO}_{2}$ revealed weakly negative values, indicating the possible surface charge modification with organic coating. ${ }^{13,14}$ The particle size distribution of $\mathrm{ZnO}$ in aqueous suspension showed some agglomerates, while that of $\mathrm{SiO}_{2}$ was very narrow and a similar size to the result from the microscopic analysis.

\section{Toxicity evaluation}

This study was performed to evaluate the no observed adverse effect level (NOAEL) and systemic toxicity effects following 90-day repeated dose of two different sizes and two opposite charges of $\mathrm{ZnO}, \mathrm{ZnO}^{\mathrm{SM} 20(-)}$ and $\mathrm{ZnO}^{\mathrm{SM} 20(+)}$. $\mathrm{ZnO}^{\mathrm{SM} 20(-)}$ and $\mathrm{ZnO}^{\mathrm{SM} 20(+)}$ were orally administrated for 90 days with a 14-day recovery period at dose levels of 125,250 , and $500 \mathrm{mg} / \mathrm{kg}$. The results of repeated doses of 90-day oral toxicity with $\mathrm{ZnO}^{\mathrm{SM} 20(-)}$ and $\mathrm{ZnO}^{\mathrm{SM} 20(+)}$ in Sprague Dawley (SD) rats revealed changes in salivation, stomach, pancreas, and eye, which were considered to be related to the treatments. Among the changes, lesions in the stomach, pancreas, and eye were considered adverse effects. Hence, target organs for the $\mathrm{ZnO}$ nanotoxicity could be the pancreas, eye, and stomach. Since the adverse changes were observed at doses more than $125 \mathrm{mg} / \mathrm{kg}$, NOAEL could not be determined, but the lowest observed adverse effect level was considered to be $125 \mathrm{mg} / \mathrm{kg}$ in both sexes in SD rats. When $\mathrm{ZnO}^{\mathrm{AE} 100(-)}$ and $\mathrm{ZnO}^{\mathrm{AE} 100(+)}$ were orally administrated for 90 days and recovered in 14 days with dose levels of $31.25,125$, and $500 \mathrm{mg} / \mathrm{kg}$, changes in salivation, submucosal edema, inflammatory cell infiltration in glandular stomach, chronic inflammation, acinar cell apoptosis in pancreas, retinal atrophy in the eye, and abscess with the proliferation of epithelium in prostate gland were observed. The significant toxic changes were observed at concentrations below $125 \mathrm{mg} / \mathrm{kg}$, therefore, the NOAEL could be considered $31.25 \mathrm{mg} / \mathrm{kg}$ in both sexes, and the target organs were pancreas, eye, stomach, and prostate gland.

In order to evaluate the NOAEL and systemic toxic effects, 90-day repeated doses of two different sizes and opposite charges of $\mathrm{SiO}_{2}\left(\mathrm{SiO}_{2}{ }^{\mathrm{EN} 20[-]}\right.$ and $\left.\mathrm{SiO}_{2}{ }^{\mathrm{EN} 100[-]}\right)$ were also performed. $\mathrm{SiO}_{2}{ }^{\mathrm{EN} 20(-)}$ and $\mathrm{SiO}_{2}{ }^{\mathrm{EN} 100(-)}$ were orally administrated for 90 days and recovered in 14 days with dose levels of $500,1,000$, and $2,000 \mathrm{mg} / \mathrm{kg}$. The significant toxic change was not observed to be $2,000 \mathrm{mg} / \mathrm{kg}$, hence, the NOAEL was considered to be above $2,000 \mathrm{mg} / \mathrm{kg}$ in both sexes. No target organ was identified. $\mathrm{SiO}_{2}{ }^{\mathrm{EN} 20(\mathrm{R})}$ and $\mathrm{SiO}_{2}{ }^{\mathrm{EN} 100(\mathrm{R})}$ were orally administrated for 90 days and recovered in 14 days at dose levels of $62.5,250$, and $1,000 \mathrm{mg} / \mathrm{kg}$. Since no significant toxic change was observed at the concentrations of $1,000 \mathrm{mg} / \mathrm{kg}$, NOAEL could be considered as above $1,000 \mathrm{mg} / \mathrm{kg}$ in both sexes. No target organ was identified.

$\mathrm{Next}, \mathrm{ZnO}^{\mathrm{SM} 20(-)}$ and $\mathrm{ZnO}^{\mathrm{SM} 20(+)}$ were dermally administrated for 90 days and recovered in 14 days with dose levels of 250,500 , and $1,000 \mathrm{mg} / \mathrm{kg}$. Clinical signs from the administration of the test substances were hyperkeratosis at the administrative regions, but it was not considered to be the direct effects by the test substances. Therefore, the NOAEL was considered to be above $1,000 \mathrm{mg} / \mathrm{kg}$ in both sexes. No target organ was identified.

From the results of genotoxicity of $\mathrm{ZnO}$ and $\mathrm{SiO}_{2} \mathrm{NPs}$, no mutagenic potential, chromosome aberrations, and micronucleus formation were observed in bone marrow cells of mice from administrations of any type of $\mathrm{ZnO}$ and $\mathrm{SiO}_{2} \mathrm{NPs}$. Also, $\mathrm{ZnO}$ and $\mathrm{SiO}_{2}$ did not influence DNA damage in the bone marrow cells, liver, and stomach from the repeated dose 90-day toxicity study.

To investigate the effect of $20 \mathrm{~nm} \mathrm{ZnO} \mathrm{NPs} \mathrm{on} \mathrm{reproduc-}$ tion toxicity according to surface charge, the teratogenicity studies were performed by following oral administrations to $\mathrm{SD}$ rats. Oral administration of $\mathrm{ZnO}$ NPs significantly decreased the body weight of maternal rats at gestation day 20 in the $400 \mathrm{mg} / \mathrm{kg}$ group. In addition, body weights of fetuses in the $400 \mathrm{mg} / \mathrm{kg}$ treatment group were also decreased at Cesarean section. Upon visceral examinations, treatmentrelated anomalies such as misshapen thymus, hypertrophy of auricle, dilatation and flexion of ureter, and ectopic kidney were observed in the $400 \mathrm{mg} / \mathrm{kg}$ group. Therefore, under the present experimental conditions, the NOAEL of the $\mathrm{ZnO}^{\mathrm{SM} 20(+)}$ was considered $200 \mathrm{mg} / \mathrm{kg}$ for dams and embryo-fetal development. The NOAEL of the $\mathrm{ZnO}^{\mathrm{SM} 20(-)}$ was considered $200 \mathrm{mg} / \mathrm{kg}$ for dams and $400 \mathrm{mg} / \mathrm{kg}$ for the embryo-fetal development.

The long-term oral intake of $\mathrm{ZnO}$ and $\mathrm{SiO}_{2}$ NPs caused in vitro and in vivo immunotoxicities by targeting mainly lymphocytes and innate immunocytes, of which the mechanistic nature could be a minor immunosuppression. This could have important implications for individuals who may have been chronically exposed to ZnO NPs.

Assessment of potential of skin irritations was estimated using a human skin equivalent model and an animal model. ${ }^{8,15}$ Next, the evaluation of skin phototoxicity was tested by the 3T3 neutral red uptake test. Lastly, the potential of skin sensitization was evaluated by a local lymph node assay. $\mathrm{ZnO}$ NP treatment decreased the cell viability of keratinocyte. However, ZnO NPs did not seem to be dermal sensitizers, and they did not induce skin irritation. The potential mechanisms 
of $\mathrm{ZnO}$ NPs for inducing and increasing oxidative stresses leading to cellular apoptosis were investigated with human keratinocytes. ${ }^{8}$ Indeed, $\mathrm{ZnO}$ NPs induced and increased significant intracellular reactive oxygen species (ROS) and mitochondrial ROS production. Therefore, it seemed that induced cellular ROS levels by ZnO NPs led to the dissipation of the mitochondrial membrane potentials and elicited cellular apoptosis. $\mathrm{SiO}_{2}{ }^{\mathrm{EN} 20(-)}$ treatment decreased the cell viability of keratinocyte, but $\mathrm{SiO}_{2}{ }^{\mathrm{EN} 20(\mathrm{R})}, \mathrm{SiO}_{2}{ }^{\mathrm{EN} 100(-)}$, and $\mathrm{SiO}_{2}{ }^{\mathrm{EN} 100(\mathrm{R})}$ did not affect cytotoxicity. ${ }^{15}$ The results for $\mathrm{SiO}_{2} \mathrm{NPs}$-induced ROS generation were consistent with the cytotoxicity test by $\mathrm{SiO}_{2}$ NPs. Furthermore, no $\mathrm{SiO}_{2}$ NPs induced phototoxicity, acute cutaneous irritation, or skin sensitization.

\section{Toxicokinetics}

In vivo toxicokinetic studies of $\mathrm{ZnO}$ NPs with oral administration to SD rats were performed according to the particle sizes and surface charges. ${ }^{16-18}$ Absorption and tissue distribution of ZnO NPs were not significantly dependent on particle sizes or sex of the rat, but larger particles, $100 \mathrm{~nm}$ ZnO NPs, revealed slower clearance from animals than $20 \mathrm{~nm} \mathrm{ZnO} N P s$. On the other hand, $\mathrm{ZnO}^{\mathrm{SM} 20(-)}$ had a higher rate of absorbance into the systemic circulation than the positively charged NPs of the same size. Common target organs for the accumulation of $\mathrm{ZnO}$ NPs were determined to be kidney, liver, and lung, regardless of NP size, surface charge, or sex of the animal. It seemed that a major form of $\mathrm{ZnO}$ NPs in tissues was an ionic form, not a particulate form, which may have formed new zinc-sulfide bond in tissues. Ionic zinc could probably interact with cysteine-rich proteins such as metallothionein in uptake systems to various tissues. Parts of ZnO NPs could be ionized under gastric condition, but pharmacokinetic behaviors of $\mathrm{ZnO}$ NPs were different from those of zinc ion. Urinary excretion played a minor role in the elimination of $\mathrm{ZnO}$ NPs while the majority of NPs were cleared via feces, suggesting that biliary and fecal excretions were involved in their clearances. Plasma concentration-time profiles following 90-day repeated oral administration showed that more than $250 \mathrm{mg} / \mathrm{kg}$ of particles could be accumulated in the body.

As the results of in vivo toxicokinetic studies of $\mathrm{SiO}_{2} \mathrm{NPs}$ show, according to particle sizes following oral administration to rats, absorption of $\mathrm{SiO}_{2} \mathrm{NPs}$ was low (about 1\% 5\%) in comparison with $\mathrm{ZnO}$ NPs by about 20\% 30\%, and their absorptions (20 nm and $100 \mathrm{~nm}$ ) and biodistributions were not significantly affected by particle size or sex of the rat. Biliary and fecal excretions played major roles in elimination of $\mathrm{SiO}_{2} \mathrm{NPs}$, but larger particles $(100 \mathrm{~nm})$ were cleared much slower than $20 \mathrm{~nm}$ NPs. The liver and kidney were suggested as common target organs for $\mathrm{SiO}_{2} \mathrm{NPs}$. Transmission electron microscopy images revealed that the $\mathrm{SiO}_{2}$ NPs were present as particulate forms in the liver, but decomposed particle morphology was found in the kidney, indicating that $\mathrm{SiO}_{2}$ NPs could be excreted via urine after complete decomposition. Plasma concentration-time profiles following 90-day repeated oral administration showed that the $\mathrm{SiO}_{2}$ NPs up to highest tested dose, 2,000 mg/kg, did not accumulate in the plasma and were cleared from the body.

\section{Peer review}

Figure 3 illustrates the research directions and progression of the entire system. First, the peer review committee, classified by professional fields, was recommended and invited to review the reports from various toxicity tests to ensure the reliability of the three tests, which include the 90-day repeated administration toxicity test, genetic toxicity test, and reproduction toxicity test. These lengthy investigations were performed at the Korea Testing and Research Institute (Seoul, Korea) with approval of and in accordance with the principles of Good Laboratory Practice.

After organizing the peer review committee, NP toxicity studies were collected and evaluated for review by a multistep process. First, the committee searched and collected references on NPs in three different categories: physicochemical properties, in vitro toxicokinetic studies, and in vivo toxicokinetic studies. The Korea Testing and Research Institute and executive office then wrote a toxicity test report, which was circulated to each member of the committee. The report on toxicity studies of $\mathrm{ZnO}$ and $\mathrm{SiO}_{2}$ NPs was evaluated

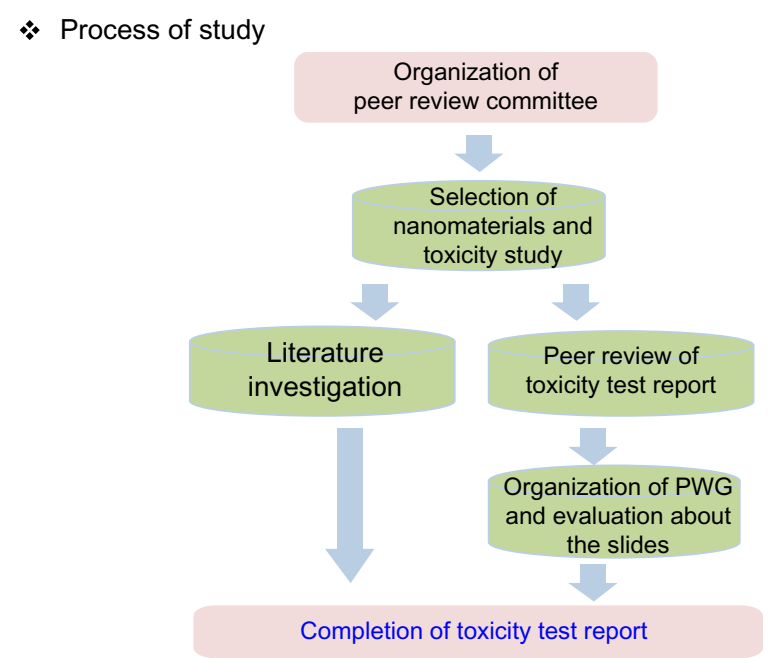

Figure 3 The entire system and research direction for the establishment of reliable nanotoxicity data.

Abbreviation: PWG, pathology working group. 
by the reviewers, including independent scientists, who had no academic or financial conflicts of interests. All members of the peer review committee provided opinions and ideas (Table 2).

The last step of the peer review process was to establish the pathology working group and create tissue pathology slides for reevaluation. These slides are reviewed by pathologists on the committee, who provide analysis and comment.

\section{Risk communication}

Based on the results of the above five steps, the aim of the sixth step was to establish and initiate the NPs risk communication system by engaging academics, industries, and the public. Some studies described the need for manufacturers, researchers, and experts on NPs to establish the basic toxicological concepts of nanomaterials and nanoproducts, and information regarding accurate risk assessment of NPs and nanomaterials and the guidelines for nanomaterial labeling should be made available to customers for a better understanding of nanoproducts. ${ }^{19-21}$ Likewise, we found that consumers believed there was a need for education and promotion of relevant information to address nanotechnology. Furthermore, we observed that consumers chose the central government as the appropriate agency for such nano education. In order to meet consumers' expectations, a communication system among multiple stakeholders of nanomaterials must first be

Table 2 List of toxicity test reports of nanomaterials

\begin{tabular}{|c|c|c|}
\hline Materials & Report title & Language \\
\hline $\mathrm{ZnO}, \mathrm{SiO}_{2}$ & $\begin{array}{l}\text { Physicochemical characterization } \\
\text { on nanomaterials. Physicochemical } \\
\text { properties of } \mathrm{ZnO} \text { and } \mathrm{SiO}_{2} \\
\text { nanomaterials }\end{array}$ & Korean/English \\
\hline $\mathrm{ZnO}^{\mathrm{SM} 20(+/-)}$ & $\begin{array}{l}\text { Repeated dose } 90 \text {-days oral toxicity } \\
\text { of } \mathrm{ZnO} \text { in rat } \\
\text { Genotoxicology of } \mathrm{ZnO} \\
\text { Teratogenicity study of } \mathrm{ZnO} \text { in rat }\end{array}$ & Korean/English \\
\hline $\mathrm{ZnO} \mathrm{AEIO0(+l-)}^{\mathrm{A}}$ & $\begin{array}{l}\text { Repeated dose } 90 \text {-days oral toxicity } \\
\text { of } \mathrm{ZnO} \text { in rat } \\
\text { Genotoxicology of } \mathrm{ZnO}\end{array}$ & Korean/English \\
\hline $\mathrm{SiO}_{2}^{\mathrm{EN} 20(-/ \mathrm{R})}$ & $\begin{array}{l}\text { Repeated dose } 90 \text {-days oral toxicity } \\
\text { of } \mathrm{ZnO} \text { in rat } \\
\text { Genotoxicology of } \mathrm{ZnO}\end{array}$ & Korean/English \\
\hline $\mathrm{SiO}_{2} \mathrm{ENIO0}^{-(-R)}$ & $\begin{array}{l}\text { Repeated dose } 90 \text {-days oral toxicity } \\
\text { of } \mathrm{ZnO} \text { in rat } \\
\text { Genotoxicology of } \mathrm{ZnO}\end{array}$ & Korean/English \\
\hline $\mathrm{ZnO}, \mathrm{SiO}_{2}$ & $\begin{array}{l}\text { Toxicokinetic study of nanoparticles } \\
\left(\mathrm{ZnO} \text { and } \mathrm{SiO}_{2}\right) \text { in rat }\end{array}$ & Korean/English \\
\hline
\end{tabular}

Abbreviations: $\mathrm{R}$, L-arginine; $\mathrm{SiO}_{2}$, silica; $\mathrm{SiO}_{2}{ }^{\mathrm{ENIO0}(-/ \mathrm{R})}, 100 \mathrm{~nm}$ negatively charged or R-coated $\mathrm{SiO}_{2} ; \mathrm{SiO}_{2}^{\mathrm{EN2O}(-/ \mathrm{R})}, 20 \mathrm{~nm}$ negatively charged or R-coated $\mathrm{SiO}_{2} ; \mathrm{ZnO}$, zinc oxide; $\mathrm{ZnO}^{\mathrm{AEI} 100(++)}, 100 \mathrm{~nm}$ positively or negatively charged $\mathrm{ZnO}$; $\mathrm{ZnO}^{\mathrm{SM} 20(++-)}, 20 \mathrm{~nm}$ positively or negatively charged $\mathrm{ZnO}$. established. Furthermore, the safety and risk assessment system for nanomaterials should be formed, and results from such studies should be reviewed by experts in the field and by a public relations group prior to public communications. Finally, scientific evaluations from preset guidelines should be employed to steer product management and oversee regulations on nanomaterials.

\section{Conclusion}

The main objective of this study was to obtain the toxicity data for NPs with diverse physicochemical properties using developed toxicity test methods. In order to facilitate the investigations, RT-NASA was organized and divided into three parts, I, II, and II, having different research topics. RT-NASA investigators proceeded in six steps: need assessment, physicochemical properties, toxicity evaluation, toxicokinetics, peer review, and risk communication. Different sized $\mathrm{ZnO}$ and $\mathrm{SiO}_{2}$ NPs were coated with three various materials to modify the surface charge, which resulted in eight different nanomaterials. Their short- and long-term toxicity assessments and evaluations were performed and presented here.

\section{Acknowledgments}

This research was supported by a grant (10182MFDS991) from the Ministry of Food and Drug Safety in 2010-2013. This study was supported by the Research-Driven Hospital Project of Korea University Anam Hospital, accredited by the Korean Government of Ministry of Health and Welfare in 2013 .

\section{Disclosure}

The authors report no conflicts of interest in this work.

\section{References}

1. Park HG, Yeo MK. Comparison of gene expression changes induced by exposure to $\mathrm{Ag}, \mathrm{Cu}-\mathrm{TiO}_{2}$, and $\mathrm{TiO}_{2}$ nanoparticles in zebrafish embryos. Mol Cell Toxicol. 2013;9(2):129-139.

2. Oberdörster G, Maynard A, Donaldson K, et al. Principle for characterizing the potential human health effects from exposure to nanomaterials: elements of a screening strategy. Part Fibre Toxicol. 2005;2:8-43.

3. European Commission. Scientific Committee On Emerging and Newly Identified Health Risks. Brussels: European Commission; 2006. Available from: http://ec.europa.eu/health/archive/ph_risk/ committees/04_scenihr/docs/scenihr_o_003b.pdf. Accessed July 15, 2014.

4. Patel D, Kell A, Simard B, et al. Cu2+-labeled, SPION loaded porous silica nanoparticles for cell labeling and multifunctional imaging probes. Biomaterials. 2010;31(10):2866-2873.

5. Liu YJ, Yang Y, Zhang CF. A concise review of magnetic resonance molecular imaging of tumor angiogenesis by targeting integrin $\alpha v \beta 3$ with magnetic probes. Int J Nanomedicine. 2013;8:1083-1093. 
6. Choi SJ, Lee JK, Jeong J, Choy JH. Toxicity evaluation of inorganic nanoparticles: considerations and challenge. Mol Cell Toxicol. 2013;9(3):205-210.

7. Bottini M, D’Annibale F, Magrini A, et al. Quantum dot-doped silica nanoparticles as probes for targeting of T-lymphocytes. Int $J$ Nanomedicine. 2007;2(2):227-233.

8. Jang YS, Lee EY, Park YH, et al. The potential for skin irritation, phototoxicity, and sensitization of $\mathrm{ZnO}$ nanoparticles. Mol Cell Toxicol. 2012;8(2):171-177.

9. Osman IF, Baumgartner A, Cemeli E, Fletcher JN, Anderson D. Genotoxicity and cytotoxicity of zinc oxide and titanium dioxide in HEp-2 cells. Nanomedicine (Lond). 2010;5(8):1193-1203.

10. Becheri A, Dürr M, Lo Nostro P, Baglioni P. Synthesis and characterization of zinc oxide nanoparticles: application to textiles as UV-absorbers. J Nanopart Res. 2008;10(4):679-689.

11. Lin CC, Lin WH, Li YY. Synthesis of ZnO nanowires and their applications as an ultraviolet photodetector. J Nanosci Nanotechnol. 2009;9(5): 2813-2819.

12. Jin Y, Wang J, Sun B, Blakesley JC, Greenham NC. Solution-processed ultraviolet photodetectors based on colloidal $\mathrm{ZnO}$ nanoparticles. Nano Lett. 2008;8(6):1649-1653.

13. Kim KM, Kim HM, Choi MH, Lee JK, Jeong J, Lee MH, et al. Colloidal properties of surface coated colloidal silica nanoparticles in aqueous and physiological solution. Sci Adv Mat. 2014;6(7):1573-1581.
14. Kim KM, Kim TH, Kim HM, et al. Colloidal behaviors of ZnO nanoparticles in various aqueous media. Toxicol Environ Health Sci. 2012;4(2): 121-131.

15. Park YH, Bea HC, Jang Y, et al. Effect of the size and surface charge of silica nanoparticles on cutaneous toxicity. Mol Cell Toxicol. 2013;9(1):67-74.

16. Baek M, Chung HE, Yu J, et al. Pharmacokinetics, tissue distribution, and excretion of zinc oxide nanoparticles. Int $J$ Nanomedicine. 2012; 7:3081-3097.

17. Paek HJ, Lee YJ, Chung HE, et al. Modulation of the pharmacokinetics of zinc oxide nanoparticles and their fates in vivo. Nanoscale. 2013;5(23);11416-11427.

18. Chung HE, Yu J, Baek M, et al. Toxicokinetics of zinc oxide nanoparticles in rats. J Phys: Conf Ser. 2013;429:012037.

19. Cobb MD, Macoubrie J. Public perceptions about nanotechnology: risk, benefits and trust. J Nanopart Res. 2004;6(4):395-405.

20. Neil N, Malmfors T, Slovic P. Intuitive toxicology: expert and lay judgments of chemical risks. Toxicol Pathol. 1994;22(2):198-201.

21. Savadori L, Savio S, Nicotra E, Rumiati R, Finucane M, Slovic P. Expert and public perception of risk from biotechnology. Risk Anal. 2004;24(5):1289-1299.
International Journal of Nanomedicine

\section{Publish your work in this journal}

The International Journal of Nanomedicine is an international, peerreviewed journal focusing on the application of nanotechnology in diagnostics, therapeutics, and drug delivery systems throughout the biomedical field. This journal is indexed on PubMed Central, MedLine, CAS, SciSearch $\AA$, Current Contents ${ }^{\circledR} /$ Clinical Medicine,

\section{Dovepress}

Journal Citation Reports/Science Edition, EMBase, Scopus and the Elsevier Bibliographic databases. The manuscript management system is completely online and includes a very quick and fair peer-review system, which is all easy to use. Visit http://www.dovepress.com/ testimonials.php to read real quotes from published authors. 